\title{
HOMENS E MULHERES NOS ANOS 1960/70: UM MODELO DEFINIDO?*
}

\author{
Maria de Fátima da CUNHA**
}

\begin{abstract}
RESUMO
Este artigo se propõe a discutir a existência de um modelo definido e definidor de papéis femininos e masculinos nos anos 60 e 70 do século passado, que poderia delegar e atribuir distinções de gênero a homens e mulheres. A fim de entendermos, em especial, o "universo feminino" desse período, tomamos como ponto de partida o estudo de revistas destinadas ao público feminino.
\end{abstract}

Palavras-chave: mulheres, distinções de gênero, revistas.

\begin{abstract}
This article intends to discuss the existence about a female and masculine sthereotype in the 60's and 70's in the last century, that could to make gender distinctions between men and women. In order to understand the "female universe" in this period we explore magazines adressed to female people.
\end{abstract}

Key-words: women, gender distinctions, magazines.

O trabalho com revistas femininas já foi realizado por alguns pesquisadores como, por exemplo, Carla Bassanezi que, analisando-as durante o período de 1945-64, constata, a formulação e construção de um modelo dominante de família a partir de distinções de gênero que concedem aos

* Este artigo faz parte de algumas discussões que faço em um dos capítulos da minha tese de doutorado, ainda em andamento, pelo programa de História Social da Unicamp.

** Professora do Departamento de História da Universidade Estadual de Londrina (UEL PR), Doutoranda pela Unicamp. 
homens autoridade e poder sobre as mulheres, considerados os "chefes da casa". ${ }^{1}$ As mulheres, por sua vez, são definidas a partir dos papéis femininos tradicionais (principalmente mães, donas de casa e esposas) e das características consideradas "próprias das mulheres" englobadas no termo "feminilidades" (pureza, doçura, resignação, instinto materno etc.). Aos pais de família cabe sustentá-la com o seu trabalho, enquanto que as esposas devem se ocupar das tarefas domésticas, dos cuidados com os filhos e da atenção ao marido.

Essas relações, segundo Bassanezi, são definidas por um conjunto de normas sociais, mas aparecem em termos de representações como naturais, desistoricizadas e válidas para todas as classes. O casamento define direitos e atribuições com relação aos gêneros traduzidos, freqüentemente em desigualdades e dominação do feminino pelo masculino. ${ }^{2}$ Ainda para Bassanezi, é necessário lembrar que durante o período de 1945-64, a sociedade brasileira vive uma série de transformações proporcionadas, entre outros fatores, pelo desenvolvimento econômico: processo de crescimento urbano e industrial, aumento das possibilidades nos campos profissional e escolar, tanto da população em geral quanto da feminina. No entanto, ao mesmo tempo em que discriminações de gênero se manifestam com intensidade - divisões rígidas de papéis e atribuições, valorização da virgindade, manutenção da dupla moral sexual, autoridade do marido sobre a mulher certas distâncias entre homens e mulheres se reduzem como, por exemplo, a modificação de regras sociais que vão do namoro à intimidade do relacionamento familiar, onde a voz feminina passa a ser mais respeitada. $\mathrm{O}$ trabalho da mulher, especialmente a de classe média - pois as mulheres pobres tiveram sempre como vivência o trabalho fora de casamento - ainda que cada vez mais comum, continua cercado de preconceitos e encarado como subsidiário ao trabalho do "chefe da família", o homem.

Assim, seguindo as pistas abertas por Carla Bassanezzi, é possível perceber, principalmente por meio das publicações destinadas ao público

1 BASSANEZI, C. Virando as páginas, revendo as mulheres. Revistas femininas e relações homem-mulher. 1945-1964. Rio de Janeiro: Civilização Brasileira, 1996.

2 Conferir, também da mesma autora: Revistas femininas e o ideal de felicidade conjugal. Cadernos Pagu, Campinas, n. 1, p. 112, 1993. 
feminino ${ }^{3}$ da época, múltiplas facetas da mulher, que ora reproduzem o modelo dominante, ora desvendam uma outra mulher que começa a "ousar", revelando, desse modo, um momento em que se coloca a possibilidade de ruptura dos papéis femininos tradicionais.

Entretanto a quebra desse modelo dominante não era tão fácil, naquele momento. Através das reportagens de várias revistas percebemos, ao lado da militante "subversiva" presa, a Miss Brasil, a modelo famosa, a garota hippie, a mãe solteira ou a atriz de novela televisiva. Todavia, as mudanças parecem ser lentas e graduais e o que é mais comum é a reprodução dos discursos dominantes que delimitam e forjam os lugares sociais de homens e mulheres. Do mesmo modo, naquele momento, é possível percebermos que diversas questões e tabus ainda chocam a sociedade e a discussão aberta sobre temas como o aborto, a sexualidade dos jovens, a infidelidade feminina ou a gravidez de moças solteiras, ainda era uma excepcionalidade. Vários destes tópicos fizeram parte de reportagens especiais em revistas da época, provocando grande sensação e "cortes" da censura que, então, vigorava.

O que chama mais atenção nas páginas de algumas revistas - Realidade, O Cruzeiro, Claudia, Manchete ${ }^{4}$-é o interesse cada vez mais acentuado para com a sexualidade da juventude e as alterações comportamentais que se desencadeavam, questões essas quase sempre verificadas através de pesquisas encomendadas.

3 Segundo Dulcília Buitoni, o conceito de "imprensa feminina" é definitivamente sexuado, ou seja, o sexo de seu público faz parte de sua natureza. Ainda para a autora, desde que surgiu no mundo ocidental, no final do século XVII, já trouxe a destinação às mulheres no próprio título, prática que persiste até hoje. Buitoni também enfatiza que, na imprensa em geral, tal distinção de público não aconteceu no passado. Embora lidos predominantemente por homens - os únicos letrados que lhes tinham acesso - os jornais eram destinados às pessoas de ambos os sexos. Não existia uma imprensa masculina. A mulher, então, faz parte da caracterização da imprensa feminina, seja como receptora e, às vezes, como produtora também. Todavia, para Buitoni, o elemento definidor para caracterizar tal distinção ainda é o sexo de suas consumidoras. Cf. BUITONI, D. S. Imprensa feminina. São Paulo: Ática, 1990. p. 7-8. (Série Princípios). Conferir, também da mesma autora: Mulher de Papel: a representação da mulher pela imprensa feminina brasileira. São Paulo: Loyola, 1981.

4 A revista Realidade não pode ser considerada revista feminina, embora às vezes publicasse matérias assinadas por Carmem da Silva. No entanto, as revistas O Cruzeiro, Manchete e Claudia podem ser qualificadas como "publicações femininas". A revista $O$ Cruzeiro é a mais antiga delas sendo lançada em 1928, e tendo grande popularidade nas décadas de 40 e 50. Manchete, da editora Bloch, foi publicada pela primeira vez em 1952 e, finalmente Claudia, que saiu em 1961, pela editora Abril, teve como objetivo atender a uma busca de identidade da mulher de classe média urbana, e também estimular e ser estimulada por todo um consumo emergente. Claudia também inaugurou um novo estilo de editar moda, beleza, culinária e decoração, aspectos essenciais e definidores das publicações destinadas ao público feminino. A esse respeito conferir BUITONI, op. cit., p. 49 
Entre estas preocupações vemos, por exemplo, o aborto e o controle da natalidade.Com relação ao aborto, a grande prioridade era entender por que a mulher o praticava e os motivos encontrados eram vários. ${ }^{5}$ As questões morais e éticas, relacionadas ao tema, também eram debatidas partindose do fato de o aborto ser um crime perante as leis brasileiras e ser condenado pela igreja. Procura-se, também, entender os traumas psíquicos decorrentes da prática abortiva, explicados pela recusa da mulher a tudo aquilo que existia de mais profundo nela e que a definiria como mulher: o instinto de procriação. Noutros casos, os traumas seriam consequiência de uma espécie de culpa superimposta a si mesmas, devido à censura existente na sociedade. Em alguns momentos, nota-se por parte das revistas, uma tentativa de dar ao tema um tratamento mais aprofundado, entendendo-o como um problema que não era exclusivo da mulher, atingindo também toda a sociedade, percebida como essencialmente masculina e que, como tal, estabelecia leis sobre o assunto, sem querer comprometer-se muito com ele.

O controle da natalidade, por sua vez, merecia igual atenção e era apresentado como um tema muito complexo, pois de acordo com a legislação da época, ninguém podia anunciar qualquer processo, substância ou objeto destinado a provocar aborto ou evitar gravidez. Por causa dessas proibições, os laboratórios não podiam utilizar a palavra "anticoncepcional" nos rótulos dos produtos. As pílulas eram comercializadas como medicamentos para "regularizar a menstruação", preservativos, como "protetor masculino", cremes e geléias destinados a "higiene íntima da mulher". Apesar da difusão e do número cada vez maior de marcas de pílula, as dúvidas a respeito do seu uso eram muitas: "Como funcionam? São seguras? Por quanto tempo as mulheres podem tomá-las? Elas causam câncer ou deformam os bebês no período da gestação?" Entretanto, vale lembrar que, apesar do temor inicial relativo ao seu uso, a pílula anticoncepcional será um

5 Segundo Buitoni, desde o anos 50 até meados de 70, a censura interna das editoras e a censura governamental permitiam avanços extremamente vagarosos no tratamento da questão sexual. Não se podia, por exemplo, nomear as partes do aparelho genital feminino, mesmo pelos nomes científicos, só era possível descrevê-los. Havia problemas para publicar desenhos, ainda que esquemáticos, fotos eram proibidas. A partir da segunda metade da década de 70, com a liberação, a imprensa brasileira foi marcada pela presença do sexo, agora já associado ao consumo. Cf. BUITONI, op. cit., p. 66-67.

6 A LEI proíbe anunciar métodos para evitar gravidez. Realidade, maio 1966. 
dos grandes detonadores da revolução sexual que proporcionará à sexualidade feminina a possibilidade de busca exclusiva do prazer, plenamente desvinculada da procriação.

Ainda no campo da sexualidade e dos novos comportamentos adotados pelos jovens e pelas mulheres, uma das situações que chama mais atenção e incomodam a sociedade desse período é a existência de mulheres que optam pela maternidade fora do casamento. Conseguir um depoimento de uma mulher que tivesse passado por essa experiência não era muito fácil. Todavia, em alguns casos, alguém vinha a público narrar a sua história, desde que a sua identidade fosse mantida em sigilo:

\begin{abstract}
...Mas por que fazer drama de uma coisa tão simples, tão normal? Se não é normal porque alguém disse que é preciso casar na Igreja, de véu e grinalda, papel no cartório, tomar o nome do marido, morar na mesma casa que ele, depender dele, ter muitos filhos e netos, então eu estou fora disso. Não acho isso válido... ${ }^{7}$
\end{abstract}

Se, por um lado, temos um exemplo tão de vanguarda e "avançado" no comportamento feminino, por outro, é possível nos depararmos também com um acontecimento que deixaria qualquer "feminista radical" muito exacerbada: os concursos de beleza feminina, definidos por alguns como a expressão maior da identidade mulher/objeto.

É impressionante (especialmente se pensarmos o quanto esses concursos já não têm a mesma receptividade, sendo substituídos por outros tipos de disputa de beleza) a atenção que essas competições obtinham por parte da imprensa, merecendo reportagens que se avolumavam para além de vinte páginas! Os leitores poderiam saber as medidas das candidatas em polegadas, os mexericos dos bastidores e os milhões gastos com as roupas. Com relação à vencedora, era possível conhecer particularidades da vida pessoal, desde o que ela comia no café da manhã, até toda a sua história de vida.

Tal situação se verificou quando a baiana Marta Vasconcelos foi eleita Miss Universo, em 1968. Um dos pontos que mais chamava atenção na

7 SOU mãe solteira e me orgulho disso. Realidade, maio 1966. 
trajetória da "professorinha" que havia chegado a Miss Universo era o depoimento do pai sobre a filha. Segundo esse, a filha sempre recebera convites para participar de concursos, mas não se sabia por que ela havia aceito aquele ano, "influência das amigas talvez", de qualquer forma, para o pai, "ela estava noiva e só quem poderia mesmo resolver o seu futuro seria o Reinaldo, o noivo, que dera consentimento na sua participação no concurso. É interessante perceber como ao longo da reportagem essa dependência do consentimento do noivo, com relação a vários setores da vida da Miss, é reafirmada pelo pai: "O que ela decidir com o noivo está decidido (...) o Reinaldo está confiante e apenas espera que ela chegue, para terem uma conversa a sós." ${ }^{\prime 8}$ Tudo isso nos indica uma possível transferência de tutela sobre a mulher, do pai ao marido. Experiência que, certamente, seria/é muito comum no âmbito da vida de grande parte das mulheres.

Interrogações sobre o que os homens pensavam sobre determinados assuntos, em especial aqueles que diziam respeito à relação afetiva, também eram presentes nas publicações destinadas às mulheres. Numa tentativa de avaliação e de entendimento do "universo mental masculino", especificamente, o que "eles pensavam sobre elas" e o relacionamento ho$\mathrm{mem} /$ mulher, a revista Realidade faz uma pesquisa e publica, à guisa de balanço e avaliação, um artigo da psicóloga Carmem da Silva - que informou e formou a cabeça das brasileiras durante algumas décadas -, publicando diversos artigos em periódicos destinados ao público feminino. A análise de Carmem da Silva apresenta alguns aspectos reveladores do homem brasileiro como, por exemplo: “...o brasileiro é acima de tudo um moderado e em matéria de mulheres só aprecia dois tipos: a própria que êle costuma chamar de 'minha senhora'; e as restantes. Deduzindo das restantes: mãe, avós, irmãs e filhas que são sagradas e intocáveis." 9

Ainda para Carmem da Silva, a "minha senhora", a eleita, deveria ser diferente "das outras" - imagem calcada, sobretudo, na lembrança da mãe -, possuidora de virtudes domésticas, beleza que atraísse o olhar dos outros homens e recato que os mantivessem à distância. E mais: simplicida-

8 MANCHETE. Rio de Janeiro: Boch, n. 848, jan. 1968.

9 SILVA, C. da. Ele se acha o bom. Realidade, dez. 1969. 
de, modéstia, economia, humor, habilidade de se calar na hora certa. ${ }^{10}$ Entretanto, todos esses atributos ficariam reduzidos a nada se um requisito fundamental não se apresentasse: a virgindade, condição exigida por $83 \%$ dos brasileiros. Afinal a "minha senhora" tinha que ser uma "moça de respeito", o que significava não deixar "avançar o sinal" durante o namoro e o noivado. Se ela cedesse aos apelos e súplicas dos homens, a mulher estaria desqualificada para um "compromisso mais sério", pois quem garantiria a ele que ela não iria dar "provas de amor" a outros, também.

Encontrada definitivamente a mulher que se encaixasse no ideal desejado, o brasileiro comum decidia, segundo Carmem da Silva, "dar um jeito na vida", ou seja, optava pelo casamento. O "dar um jeito na vida" significava, de forma sucinta, garantir refeições saborosas e baratas todos os dias, camisas limpas, botões costurados, sapatos engraxados e sexualidade legalizada. ${ }^{11}$ Em um outro momento, a mesma Carmem da Silva desvenda, de forma irônica e cômica, um outro perfil do homem brasileiro ao falar sobre a arte de dar "cantadas", definida por ela como a arte de estabelecer uma aproximação rápida e a mais íntima possível com um elemento do sexo oposto:

Com a evolução e, principalmente, com a instituição do casamento monogâmico, foi preciso adotar métodos de cantada que não deixassem marcas. Foi abolido o uso de instrumentos cortantes, perfurantes ou contundentes. Uma cantada em bom estilo exige um tipo de abordagem que não provoque reações defensivas. Já se sabe que mulher é teimosa: depois de ter dito não é pràticamente inútil mudar de tática para arranjar-lhe um sim.

Para ela, em raríssimas situações a cantada partia da mulher, sendo quase sempre de iniciativa masculina: "Esse processo requer pretexto mais

10 Carmem da Silva em sua seção "A Arte de Ser Mulher", na revista Claudia, publicada de 1963 até a sua morte em 1985, abriu espaço para se tratar da problemática feminina de modo corajoso e instigante, contribuindo, segundo Dulcília Buitoni, para maior consciência de algumas gerações de mulheres. Quando, nos anos 60, o sexo começava a se insinuar em algumas matérias, falando-se em controle de natalidade, ela foi a primeira a começar a falar do tema de forma mais profunda, e, também a primeira a colocar a questão do prazer.

11 SILVA, op. cit. 
ou menos válidos: já o sabiam nossos avós. Eles nunca saiam de casa sem levar no bôlso alguns lencinhos de renda e luva de pelica, para achá-los no caminho" [grifo da autora]. ${ }^{12}$

Continuando, Carmem da Silva enumera os vários estilos de cantada que variava conforme o seu "executor":

...O ardente é de inspiração mediterrânea. O homem trata por todos os meios de demonstrar à mulher que ou a consegue imediatamente, ou morre vítima de apoplexia. Arregala os olhos, fala em tom entrecortado; suas mãos se descontrolam e se multiplicam.

$O$ dramático é calcado no modêlo mexicano. Intenso, exigente feroz, ameaçador(...) $O$ disfarçado é um dos estilos tipicamente brasileiros. O rapaz não quer nada, mas nada mesmo, só a companhia e o papo (...) Pega no queixo mas não quer nada só observar certo ângulo do rosto. E vai indo, vai indo - tudo sem querer nada. $O$ intelectual acredita piamente que a História, a Sociologia, a Psicanálise devem fatalmente desembocar em seu leito. Mulher inteligente e evoluída tem de ser sexualmente livre... em benefício dêle... ${ }^{13}$ [grifos no original].

Fico imaginando se homens e mulheres quando liam esse texto, à época conseguiam perceber a natureza crítica, irônica e risível da autora, ou se carregavam no bolso para fazerem uso, cada um com interesse próprio. Carmem da Silva, também inovava ao não deixar que o seu discurso acabasse se transformando numa bandeira a ser utilizada contra os homens. Ela conseguia perceber, e deixava claro aos leitores, que o jogo da sedução era uma rua de mão dupla, ou seja, que a mulher, longe de ser uma vítima deste, fazia uso dele:

...Até agora viu-se a cantada apenas pelo lado masculino. Mas, como não há cantada sem mulher, é necessário comentar sua posição na história (...) Muitas mulheres precisam ser cantadas para reforçar sua presença feminina, ficam felizes por despertar o desejo, ou o espetáculo do desejo masculino - o homem

12 Cf. SILVA, C. da. A arte da cantada. Realidade, jun. 1966.

13 Id. 
pendente de um sim ou de um não de seus lábios. Outras encontram na intensidade do cêrco uma desculpa para fugir à responsabilidade de seus atos: elas queriam resistir mas não puderam, a pressão foi forte demais. Mas isso é fantasia, pois a mulher tem vontade própria e só cede quando quer (...) Mas a proeza realmente artística é a que consiste em fazer virar o feitiço contra o feiticeiro, transformando em boas as péssimas intenções que o cantador alimentava. A cantada que terminou no registro civil é o melhor atestado da habilidade feminina e uma advertência que os homens não devem ignorar... [grifos no original].

Ainda no campo feminino, sérias críticas ao perfil masculino eram tecidas por várias mulheres que percebiam a existência de um extremo machismo, autoritarismo, egoísmo e vaidade nos homens na maioria das vezes, nos próprios maridos. No julgamento delas sobre o seu homem, notase uma decepção muito grande com relação a algumas facetas do relacionamento homem/mulher:

...Eu conto nos dedos os homens que existem no Brasil: não passam de dez. Os outros são cópias ridículas que perambulam por aí sobre duas pernas, porque não conseguem cair de quatro (Itala Nandi, atriz).

...No casal brasileiro não existem duas pessoas. Existem um homem e uma vírgula (Betty Faria, atriz). ${ }^{14}$

Por outro lado, algumas mulheres detectavam que todo esse comportamento do homem não era fruto unicamente da atuação "deles" no relacionamento com a mulher. Entendiam que também "elas" tinham uma participação muito grande na "leviandade" masculina, ao adotarem uma posição que permitia que esta acontecesse. Percebe-se também que alguns casais buscavam outras experiências de relacionamento considerado "moderno", procurando subverter as bases do chamado "casamento burguês". Zuenir Ventura, mais uma vez, narra em seu livro um exemplo dessa tentativa de casamento alternativo entre a atriz Maria Lucia Dahl e o cineasta Gustavo

14 A MULHER brasileira julga o seu homem. Realidade, dez. 1969. 
Dahl. O jovem casal se dava o direito ao que a convenção chamava de infidelidade, desde que confessada, sem mentiras e segredos. Pensava-se, então, que sem as noções de ciúmes e de traição, valores fetiches da moral burguesa, as relações amorosas ganhariam em consistência e solidez. Entretanto, surpreendentemente, o casamento da atriz e do cineasta terminou com uma bofetada de Gustavo em Maria Lúcia, no baile de reveillon de 1968, na casa de Heloísa B. de Hollanda. Motivo: a atriz dançava com um rapaz que o marido não aprovava. Para todos que assistiram à cena, a agressão e a posterior separação foram uma surpresa: "Logo eles?!"15 Anos depois, os dois poderiam confirmar que a teoria era uma coisa... e o coração outra.

Por razões diferentes a irmã de Maria Lúcia, Marília Carneiro também decide separar-se, apesar de não ter problema conjugal. Separa-se apenas por "curiosidade", para ver na prática como era a vida que se pregava em teoria. Essa vida, como lembra Ventura, consistia em deixar o conforto de um lar, a condição de apêndice econômico e partir para uma arriscada aventura de experimentação existencial, traduzida na busca de uma profissão, em novas e descompromissadas relações ou, às vezes, na solidão. Zuenir Ventura, também, relata uma outra experiência de relação afetiva que se iniciava naquele réveillon de 68 . Naquele dia enquanto rolava a famosa festa da Helô, um casal - ela com dezesseis anos e ele com quatorze -, Cesinha e Claudia, iriam viver sua primeira experiência sexual, os dois eram virgens. Nesse caso, o passo dado pelos dois poderia ser visto como uma raridade pois, naqueles anos uma iniciação sexual baseada no amor, principalmente para o homem, ainda era uma novidade, imperava ainda a iniciação com prostitutas e, para uma moça de família, a perda da virgindade antes do casamento, como já vimos, não era aceita pela sociedade. ${ }^{16}$

Ainda acompanhando as revistas da época (anos 60), podemos perceber a existência de sessões destinadas a esclarecer dúvidas ou dar sugestões a jovens senhoras casadas, ou moças solteiras. Tais sugestões

15 VENTURA, Z. 1968: o ano que não terminou. A aventura de uma geração. Rio de Janeiro: Nova Fronteira, 1988. p. 25.

16 Segundo Ventura, essa relação nascida nessa noite só iria ser interrompida pela repressão, em 1971, quando ele cai nas mãos da polícia e ela vai para o exílio. 
ou orientações relacionavam-se à sexualidade, trabalho e relacionamento amoroso/conjugal. ${ }^{17}$

Na revista $O$ Cruzeiro, existia uma sessão intitulada "De Mulher para Mulher", que às vezes vinha assinada por Maria Teresa. ${ }^{18}$ Em um desses editoriais considera-se a possibilidade da felicidade no casamento após muitos anos de união ${ }^{19}$ :

Certa vez perguntamos a uma espôsa aparentemente feliz se agora vinte anos depois de casada, ela ainda se julgava tão feliz como ao tempo do noivado. E ela nos respondeu: "Como não, muito mais venturosa do que naquele tempo. As promessas de ontem são a realidade de hoje. A plantinha que ontem apenas desabrochava hoje tem raízes profundas. E a segurança e o carinho que me advieram da companhia 'dêle' constituem uma dádiva inestimável com que Deus me brindou”.

Segundo o artigo da revista, essa resposta positiva e "dignificante" para o casamento, opunha-se diametralmente à opinião de certos casais ou de pessoas solteiras que afirmavam que a rotina do casamento " mata o amor". Isto é, admite-se até que o amor possa morrer, se marido e mulher fossem se fechando aos poucos no seu egoísmo e descuidando da atenção que se deveria dar um ao outro. E no prosseguimento, afirma-se que o casal que tiver a preocupação constante de constituir um par harmonioso deverá ter em mente uma dedicação recíproca que implicará, por vezes, em pequenos sacrifícios de ambas as partes. No entanto, segue o texto: "Não é necessário que um e outro abram mão de sua personalidade".

Realmente, à primeira vista, parece que mesmo tendo como proposição a manutenção da "harmonia" entre o casal, a idéia é de que a mesma aconteça tendo como pressuposto a dedicação e o respeito mútuo do casal,

17 As revistas femininas sempre exploraram a potencialidade do "consultório sentimental", seja de um modo mais sensacionalista ou desenvolvendo psicologismos. O consultório sentimental nasceu com a imprensa feminina e até hoje resiste, mesmo em publicações mais pretensiosas. Assuntos e linguagem são escolhidos de acordo com o público, mas a chave é sempre a relação amorosa, refletindo quando bem feito, ansiedades e conflitos da sociedade, vulgarizando ou aprofundando conceitos de psicologia através de matérias sobre comportamento. Cf. BUITONI, op. cit ., p. 65.

18 As semelhanças com os editoriais assinados por Carmem da Silva em Claudia, é evidente. Entretanto, Carmem da Silva inova em certos aspectos se comparada com as orientações da revista O Cruzeiro.

19 CASAR e ser feliz. O Cruzeiro, n. 30, p. 40-41, 7 maio 1960. 
sem que para tanto houvesse a necessidade de submissão ou prepotência de qualquer um dos lados da relação. Poderíamos mesmo dizer que, para os anos 60, tais discursos, ainda não de todo superados nos dias atuais, eram um grande passo em se tratando de relacionamento homem/mulher. Entretanto, um outro serviço prestado por essa sessão da revista consistia em dar conselhos a mulheres que escreviam para a revista pedindo, ao que parece, ajuda através da fala mais experiente da jornalista, com relação a "pequenos problemas" enfrentados com os seus parceiros. E, então, diante de uma situação mais concreta, os conselhos deixam de ser tão avançados. Tal situação pode ser percebida através da carta de uma leitora que é identificada apenas pelo tipo de problema que afirma estar tendo: "Êle é contra o trabalho feminino". Logo abaixo vem a sugestão oferecida pela revista:

Realmente não vemos por que a mulher trabalhe fora quando não há necessidade. O emprêgo impõe obrigações que muitas vêzes terão que entrar em conflito com as obrigações domésticas. Muitos homens se queixam de que o eterno feminino tende a desaparecer com essa "mania que as mulheres têm de competir com a gente na luta pela vida. [grifos nossos]

O que pode-se perceber é que a tal harmonia, tão falada num primeiro momento, deveria ser mantida a todo custo, principalmente a harmonia doméstica, o que poderia ser entendido como a "paz masculina", quando o homem voltasse para casa. As pequenas concessões do casal, mencionadas para a felicidade do casamento são feitas em casos como este, quais sejam, ela terá que fazer uma concessão, abrindo mão do seu desejo em nome da harmonia familiar, pois o sacrifício de trabalhar fora o marido já faz, sustentando a ela e a casa. E assim, um casamento com "pequenos sacrifícios e concessões" de ambas as partes, teria tudo para durar anos.

Os aconselhamentos não se destinavam somente às mulheres, mas também a alguns homens que escreviam pedindo orientação a respeito de seus relacionamentos. Nessa mesma coluna, respondendo a um leitor que é reconhecido apenas pelas iniciais $\mathrm{HC}$ e pelo título de sua carta que enuncia o tipo de problema enfrentado "Ela não é capaz de um sacrifício por mim", orienta-se para que ele, indeciso entre a carreira e a amada, escolha a primeira opção: 
...Não chegaria, sequer, a ser um sacrifício. Bastaria que tivesse boa-vontade para acompanhá-lo aonde o levam seus interêsses de trabalho. Não achamos razoável que prejudique sua carreira porque a môça não quer acompanhá-lo ao interior. Para garantir um futuro melhor, a pessoa tem que lutar muito, principalmente no comêço da vida. Se ela não quer ir com você, não permita que isso interfira na sua resolução de seguir. Afinal, você seria o chefe da família e é a você que compete escolher o lugar aonde vai ou onde quer morar... ${ }^{20}$ [grifos nossos]

Podemos questionar que as análises que fazemos de revistas como essa, possam sofrer as influências do tempo, dos anos percorridos desde essa época, quando muita coisa mudou e outras tantas permaneceram no mesmo patamar anterior. Acreditamos que realmente, os questionamentos deflagrados nesses anos pelas reivindicações das mulheres e de outros sujeitos sociais possam nos fazer perceber o universo masculino/feminino dos anos 60 através de uma certo olhar que mescla uma certa dose de ironia e perplexidade, principalmente quando nos encontramos diante de temas tidos, atualmente, como já superados, como o trabalho feminino fora de casa. No entanto, percebemos que tais questões à época eram muito complexas aliadas a concepções que vinham de séculos atrás. Como, por exemplo, o "eterno feminino" mencionado na resposta à leitora, que seria prejudicado ou exterminado com o trabalho feminino. Que dizer de tal concepção? Este conceito pode ser interpretado à luz do pensamento de S. Freud, que entendia que "para a mulher fazer-se feminina era necessário fazer-se mulher como a mãe, a fim de que algum dia pudesse receber do pai um bebê/ falo como os que a mãe possuía." ${ }^{21}$ Ou seja, a teoria freudiana insere os ideais de feminilidade no contexto do século XIX que identifica e alimenta a idéia da histeria feminina, ou a realização feminina ligada à maternidade e ao casamento.

Contra essas teorias levantaram-se vozes questionando as origens das mesmas. Um exemplo que pode ser citado é o de Simone de Beauvoir, em especial no seu livro $O$ segundo sexo. Nessa obra, a autora vai afirmar aquilo

20 ELA não é capaz de um sacrifício por mim. O Cruzeiro, n. 44, 13 ago. 1960.

21 Ver a esse respeito KEHL, M. R. Deslocamentos no feminino. Rio de Janeiro: Imago, 1988. p. 239. 
que se tornou um ícone/paradigma para as feministas dos anos 60/70: "não se nasce mulher, torna-se mulher". Com essa afirmação, Beauvoir entendia que existia toda uma pressão social e cultural (sexual, psicológica, política) que sufocava "as possibilidades da mulher". Para entender como era engendrado o discurso que determinava "o destino" da condição feminina, a autora identificava na biologia as origens de explicações que naturalizavam as diferenças entre os sexos. Nesse entendimento, a palavra fêmea sugeria toda uma carga de imagens fortemente negativas:

\begin{abstract}
...monstruosa e empanturrada, a rainha das térmitas reina sobre os machos escravizados; a fêmea do louva-a-deus e a aranha, fartas de amor, matam o parceiro e o devoram; a cadela no cio erra pelas vielas, deixando atrás de si uma esteira de odores perversos; a macaca exibe-se impudentemente e se recusa com faceirice hipócrita; as mais soberbas feras, a leoa, a pantera, deitam-se servilmente para a imperial posse do macho. Inerte, impaciente, matreira, insensível, lúbrica, feroz, humilhada, o homem projeta na mulher todas as fêmeas ao mesmo tempo...22
\end{abstract}

Há que se dizer que se, por um lado, essas críticas reviram sob novas perspectivas a condição feminina na sociedade ocidental, desnudando os preconceitos ancestrais dirigidos às mulheres, por outro, elaboraram um contradiscurso que reinterpretou especificidades femininas, como as biológicas, sob uma ótica, às vezes, muito negativa. Para esse novo olhar, a menstruação, a gestação e a amamentação passaram a ser vistos quase como uma maldição que escravizava e degenerava o corpo da mulher. Está claro que com essas afirmações pretendia-se subverter os papéis femininos tradicionais, consagrados ao lar e à maternidade. Assim para Beauvoir:

...contrariamente a uma teoria otimista cuja utilidade social é demasiado evidente, a gestação é um trabalho cansativo que não traz à mulher nenhum benefício individual (...) e exige, ao contrário, pesados sacrifícios (...) O parto em si é doloroso, é perigoso. É nessa crise que vemos com maior evidência que o v. 1, p. 25 . 
corpo nem sempre satisfaz a espécie e o indivíduo ao mesmo tempo (...) O aleitamento é uma servidão esgotante... ${ }^{23}$

Pode-se afirmar, então, que o propalado "eterno feminino" do texto da revista $O$ Cruzeiro, ainda trazia como exemplos de mulher e de feminilidade, senão os mesmos, alguns dos principais traços de um modelo do século anterior. É interessante notar certas particularidades na revista que sem querer também podem revelar através de outros mecanismos ou linguagens o universo feminino e masculino, desses anos que estamos perseguindo.

Esse mesmo número da revista $O$ Cruzeiro trazia como capa o presidente Jucelino Kubitchek homenageando a inauguração de Brasília. Nas reportagens sobre o evento, acumulavam-se apelos à modernidade, ao trabalho e ao esforço sobre-humano para a construção da capital, um verdadeiro combate ao pessimismo. Esse mesmo tom de modernidade era também filtrado através de anúncios de produtos destinados à dona-de-casa e ao mundo feminino. Páginas e páginas de propagandas de produtos de beleza, de limpeza, de eletrodomésticos e de higiene, convidavam homens e mulheres a fazerem parte da modernidade que acenava para os anos 60. Todavia, algumas idéias nada tinham de moderno, contradizendo a tão falada harmonia conjugal já citada e, apesar disso, ou talvez por isso mesmo, nos faça rir. Refiro-me, em especial, a uma charge do cartunista Péricles autor do famoso O Amigo da Onça, veiculado durante anos por essa revista. Nesse mesmo número, fechando a publicação, como era costume aparecer, via-se $O$ amigo da Onça no leito conjugal ao lado da esposa que perguntava: "Querido, não esquecestes o gás do banheiro aberto?”. E o marido, o próprio Amigo da Onça, com o olhar matreiro, cúmplice do leitor, usando máscara de oxigênio sob as cobertas. A intenção é clara: matá-la.

Assim, percebe-se que no Brasil dos anos 60, conviviam a idéia da modernidade, da mudança, do ideal do "casamento feliz" e também a idéia, até bem aceita, de se acabar, literalmente, com a esposa em nome da honra ou através de acidentes "bem intencionados", como sugere o quadro humorístico de Péricles. Afinal, a mulher ainda era vista, ao que parece, como 
propriedade do homem. Aquela que vai fazer concessões para proporcionar a "paz doméstica" para o marido. E todas essas idéias características, ora de modernidade, ora de ultrapassado, são aceitas, e vivenciadas, cotidianamente.

Através de vários números da revista, a sessão "De Mulher para Mulher", continua dando conselhos e orientações sobre inúmeros problemas do mundo feminino, como por exemplo, "Carinhos entre Namorados", a eterna dúvida da mulher, à época, sobre até onde deixar o homem avançar. Ou sobre as primeiras desavenças do casal e sobre infidelidade conjugal. ${ }^{24}$ Sobre esse último tema, a orientação acontece também tendo como ponto de partida uma carta de uma leitora que diz sofrer com esse problema em seu casamento. A sugestão do que ela deve fazer é muito ilustrativa do que se esperava da mulher à época:

Infelizmente o seu caso é muito mais comum do que se pode supor: homens que até então eram bons esposos e que, no começo da velhice mais dispondo agora de recursos folgados, arranjam uma aventura extraconjugal, com o que se afastam da família, deixam-se explorar, mas conseguem provar a si mesmos que ainda são capazes de suscitar paixões. Que lhe cabe fazer? Manter-se no seu lugar de honra, evitando a todo custo cenas desagradáveis que só servirão para exacerbar a paixão do seu marido pela outra (...) procura manter-se de ânimo firme, levando tanto quanto possível uma vida normal, sem descuidar do aspecto físico. Acreditamos que por êsse processo de aparente indiferença pela aventura do D. Juan êle compreenda, por si mesmo, a exploração de que está sendo vítima e o ridículo a que está exposto. [grifos nossos]

Pode-se perguntar quantas mulheres ouviram esses conselhos de suas avós, mães, pais, da família toda, em nome da paz doméstica. É claro que é fácil perceber que esse tipo de orientação era mais cômoda. Acreditamos, que a revista não poderia se responsabilizar por um outro tipo de orientação, mesmo porque separação à época, era algo muito sério. E, cre-

24 CARINHO entre os novos. O Cruzeiro, n. 33, p. 40; AS PRIMEIRAS desavenças. $O$ Cruzeiro, n. 34, p. 88, maio/jun.1960; PROBLEMAS de noivado, p. 92 e ELA não é capaz de fazer um sacrifício por mim, p. 96, O Cruzeiro, jun/ago. 1960. 
mos também que era o tipo de comportamento que se esperava de uma mulher casada, que estivesse passando por essa situação. Afinal, era a mesma atitude que suas mães e avós vinham tomando há décadas. A separação era praticamente uma saída impensável para a mulher em caso de adultério, o mesmo não valendo para o homem. No caso do homem adúltero, como o texto sugere, ele era tido como uma vítima, um explorado. Com relação à mulher adúltera, o caso era outro: ela poderia ser vista quase como uma prostituta. ${ }^{25}$ Papel que, provavelmente, também lhe seria atribuído caso se separasse, mesmo alegando adultério do marido.

É bom lembrar que tais temas prosseguirão ainda como polêmica por algumas décadas, apesar da tão falada liberação dos anos 60 e, principalmente dos anos 70. Tais permanências de comportamentos e de práticas podem ser atestadas diante, por exemplo, da vida de Leila Diniz que chocava a sociedade por ter uma filha, sendo solteira, ou por falar abertamente de seus relacionamentos amorosos, e é enganoso pensar que só a chamada sociedade conservadora e burguesa reagia de forma negativa ante personalidades como a dessa atriz. Mesmo a esquerda, por motivos um tanto diferenciados, viam-na com preocupação.

25 Mirian Goldenberg em pesquisa que busca traçar a identidade da "outra" mais precisamente da amante do homem casado, percebe alguns traços que poderíamos estender também para a mulher que comete adultério, nos anos 60 . Embora a pesquisa de Goldenberg aborde um período mais recente (anos 80/90) acreditamos que os resultados sejam válidos para as décadas que estudamos. Segundo a autora, "Representada em romances, filmes, novelas de tevê, peças de teatro e mesmo na cabeça da maior parte das pessoas como vilã, mulher fatal e perigosa, ameaça dos lares felizes e à família, a Outra, a amante do homem casado, é um personagem muito presente na vida de cada um de nós. Reais ou não, essas representações torna a Outra um ser misterioso e profano, encoberto por enigma e máscaras, que pode a tudo e a todos contaminar. É a mulher pecadora, Eva, desobediente a Deus e aos valores da sociedade, que deve permanecer escondida (ou ser destruída) para não macular a pureza das virgens das esposas fiéis. Seu destino é sempre infeliz : a morte ou a velhice solitária, como a cigarra que apenas cantou no verão. Para as formigas, as que cuidam com amor e sacrifício da moral familiar, restam as benesses sociais: os filhos, os netos, o amor eterno do marido. Odiada ou invejada, a Outra permanece oculta. Sem possuir identidade principal da mulher em nossa sociedade - 'esposa-mãe'-, esconde-se atrás de outros papéis”. Após a realização de uma série de entrevistas, Goldenberg constata a existência de um código de gênero muito forte, diferenciando atributos femininos e masculinos. O que aparece com mais destaque nos depoimentos é a diferença entre a sexualidade masculina e a feminina, sendo a do homem considerada mais "carnal" e a da mulher mais "romântica". Daí deriva, para a autora, uma moral que implica em valores diferentes para a infidelidade do homem e da mulher, sendo que a da mulher é a pior, pois ela tem que estar muito envolvida com alguém para transar, e o homem pode transar e nunca mais lembrar da pessoa. Esta diferença, segundo a autora é percebida como biológica para alguns ou cultural por outros e é apontada como traço característico distintivo fundamental entre os gêneros. Cf. GOLDENBERG, M. A outra. Estudos antropológicos sobre a identidade da amante do homem casado. Rio de Janeiro: Record,1997. p. 11, 127. 
Mas não só publicações como $O$ Cruzeiro e Claudia, e outras revistas da mesma natureza, falavam sobre o universo feminino. Revistas que, aparentemente, destinavam-se à vida em família e à saúde, ocupavam grande espaço falando às mulheres. A motivação é clara, até porque eram as mulheres que guardavam e zelavam pelo bem-estar do lar, incluindo nesses cuidados, maridos, filhos e a sua própria saúde. ${ }^{26}$ Um exemplo é a revista Vida e Saúde, uma publicação mensal que procurava abordar questões ligadas à higiene e saúde, que trazia artigos de médicos, quase todos estrangeiros, abordando diversos temas sobre a saúde da mulher, entendida a partir de seu corpo e também de seu psiquismo. ${ }^{27}$

Em um artigo intitulado "Envelheçamos Juntos", é apresentada uma tese muito interessante sobre o que o tempo traz de bom e de ruim em um relacionamento. Segundo o artigo, a "rival" feminina (leia-se a outra), não é a principal ameaça ao matrimônio. Na verdade, a rival só entraria em cena quando já existissem "erosões psicológicas" no relacionamento do casal. A principal "erosão" seria a "inexperiência" da mulher, que para o autor seria o motor principal de funcionamento do casamento. Para comprovar a sua tese, destacava que estudos levados a cabo com viúvas em suas segundas núpcias, indicavam sensivelmente a importância da "experiência" feminina: "Sabem o que delas se espera. Por essa razão, na competição para encontrar marido, as viúvas se tornam tão perigosas. Dominam, o aspecto externo, as maneiras, a apresentação, a arte de dizer o que os homens querem escutar" 28 [grifos nossos].

Na vivência das viúvas destaca-se com ênfase o fato de saber dizer (e talvez de ouvir), aquilo o que o homens queriam escutar, daí o seu perigo para as moças na grande competição de arrumar marido. Um outro fator apontado que poderia "erodir" e desmoronar por completo um casamento seria a perda da graça e do encanto por parte da esposa: "uma vez conquistado o marido, não julgou necessário fazer esforços para continuar jovem de corpo e de espírito, cultivando ambos." Continuando:

26 Segundo Dulcília Buitoni, a contigüidade do conceito família com a figura feminina, fazia com que revistas destinadas à família fossem lidas quase que exclusivamente por mulheres, o que praticamente vinculava o tema às publicações consideradas femininas.

27 No arquivo Edgar Leuenroth encontram-se os números dessa revista de 1940 até 1968, sempre com a mesma tônica em suas abordagens.

28 KAUFFAN, E. Envelheçamos juntos. Vida e Saúde, Valência, n. 3, mar. 1960. (Coleción de Estudios). 
O ter marido deu-lhe um falso sentimento de segurança, como se ela houvesse entrado na posse de um seguro de vida e pelo qual não tivesse que pagar senão a primeira prestação. (...) Não lhe ocorreu a idéia de que, para reter o marido, terá que pagar várias prestações. Desde os vinte anos, deve a mulher pensar como será aos quarenta e como gostaria de sê-lo. ${ }^{29}$ [grifos nossos]

Neste aspecto, ao mesmo tempo em que se parecia criticar a mulher por ver no casamento um "seguro de vida" pelo qual teria que pagar apenas uma prestação, também era reforçado, implicitamente, a idéia de que o casamento consistia no fim último e único da mulher, pelo qual ela deveria pagar não uma, mas várias prestações. E, para tanto, ela teria que se lembrar dos anos que viriam, se ela quisesse permanecer casada. Ou seja, o segredo do sucesso ou fracasso do casamento estava unicamente nas mãos a mulher, sendo a responsabilidade delegada exclusivamente a ela. Assim, esta deveria seguir algumas regras: ouvir o marido e, provavelmente, dizer o que ele quisesse ouvir, manter-se jovem e encantadora. Caso contrário, existiria sempre a sombra da outra, da rival, por quem seria muito natural o marido se interessar, dado o fracasso da mulher/esposa em não saber manter o casamento.

Na mesma publicação, chamam a atenção alguns artigos que tentavam entender ou explicar o efeitos das emoções na mulher. ${ }^{30}$ Narrando-se casos em que pacientes mulheres, relatavam a seus médicos sintomas que não entendiam, como desânimo, falta de apetite e palpitações, o médico passava a explicá-los como decorrentes de "falta de controle das emoções". E, logicamente, a cura viria pelo controle das mesmas:

...Tem a senhora razão (...) em pensar que seus sintomas haveriam de melhorar se suas ansiedades fôssem removidas. Acho, porém, que a visão que a senhora conseguiu ter do mecanismo pelo qual seus sintomas são produzidos, capacitála-á a pôr sob controle suas emoções, de modo que lhe seja possível encarar os fatos de maneira muito mais realista...

29 KAUFFAN, op. cit., p. 12-13.

30 SHYROCK, H. Emoções como doenças. Vida e Saúde, n. 6, jun. 1968; HUMMEL, J. Problemas psicológicos da mulher moderna - o eterno feminino. Vida e Saúde, n. 6, p. 4-5 e 18-19, jun. 1968. 
Através da fala do especialista, fica claro que além de perder o controle das emoções, a paciente tendia a fantasiar sua vida e que era necessário, portanto, reaver o seu controle emocional para ser mais realista em seu cotidiano. Ou seja, fica claro ainda que aquela "velha teoria" sobre a falta de aptidão das mulheres para terem acesso à razão, locus de fácil trânsito para os homens, ainda não é de todo ultrapassada nos anos 60.

Em outro artigo, começa-se com uma interrogação muito significativa por ela mesma: "Está hoje a mulher mais exposta às perturbações nervosas que outrora?" Colocando a princípio uma possibilidade da mulher escapar, até mais facilmente que o homem à depressão nervosa, "devido à sua maleabilidade", no seu prosseguimento, o texto passa a explicar as inúmeras causas que levariam a mulher a esta situação: "Efetivamente, há numerosas causas que favorecem, na mulher, a evolução para a depressão nervosa, êsse ‘turbilhão' em que cai quem não é capaz de suportar a angústia.” Aparentemente, 'o turbilhão' arrastaria qualquer um para a depressão, não só a mulher, mas também qualquer fraco que não tivesse forças físicas e morais para suportar a situação de angústia.

Contudo, nas mulheres as causas que a arrastariam para esse mal específico, seriam inúmeras desde aquelas relacionadas ao corpo feminino, até aquelas ligadas aos "problemas de nosso século", como as "diversas conseqüências da emancipação". Seriam três causas principais aquelas que influenciariam os problemas de ordem nervosa nas mulheres: causas físicas, causas psicológicas e causas ligadas às suas condições de vida ${ }^{31}$ :

1) da jovem: escolha do noivo, (...) mêdo da gravidez, receio de ser abandonada, risco de um casamento irrefletido...

2) da solteirona: (...) a solidão moral, sentimento de frustração da maternidade, receio da ironia e do desprêzo...

3) da mulher casada: que tem que sofrer as fúrias e os reveses do cônjuge a quem se uniu "para os bons e maus dias [grifos nossos].

31 Com relação às causas físicas são enumeradas questões ligadas à própria fisiologia da mulher, como menstruação e as perturbações pré-menstruais constantes, tudo isso chocando-se com a incompreensão daqueles que circundavam as mulheres, principalmente os homens. As causas psicológicas consideradas como "problemas da vida" de todos os tempos, são citados como assuntos femininos que trazem preocupação ou angústia. 
Acrescenta-se ainda, segundo o artigo, que as "mulheres de hoje" mudaram muito. Rivalizam, mais e mais, com seus companheiros masculinos. "Há mulheres engenheiras, médicas, pilotos, etc, casos excepcionais (...) que não satisfazem nem a própria sociedade, nem a vocação profunda de ser mulher." Essa vocação profunda da mulher é definida claramente em outra passagem: "É o casamento a condição de felicidade da mulher? Certo é que uma vocação ancestral impele a mulher para a maternidade. E só $o$ casamento, se fôr feliz, pode saciar as aspirações mais profundas da mulher..." [grifos nossos].

Pode-se concluir, através da análise dos artigos dessas revistas, que as mulheres dos anos 60 ainda carregavam o peso do estereótipo tradicional do que era "ser mulher" em suas vidas. Para aquelas que transgrediam os estreitos limites que lhes eram destinados, o mais comum a acontecer era a possibilidade quase certa do convívio com o rótulo de menina "mal falada" ou da "puta".

\section{Referências}

BASSANEZI, C. Virando as páginas, revendo as mulheres. Revistas femininas e relações homem-mulher. 1945/1964. Rio de Janeiro: Civilização Brasileira, 1996.

Revistas femininas e o ideal de felicidade conjugal. Cadernos Pagu Campinas, n. 1, 1993.

BEAUVOIR, S. de. O segundo sexo. Fatos e mitos. Rio de Janeiro: Nova Fronteira, 1980.

BUITONI, D. Imprensa feminina. São Paulo: Ática, 1990. (Série Princípios). . Mulher de papel: a representação da mulher pela imprensa feminina brasileira. São Paulo: Loyola, 1981.

GOLDENBERG, M. A outra. Estudos antropológicos sobre a identidade da amante do homem casado. Rio de Janeiro: Record, 1997. 
KHEL, M. R. Deslocamentos no feminino. Rio de Janeiro: Imago, 1988.

VENTURA, Z. 1968: o ano que não terminou. A aventura de uma geração. Rio de Janeiro: Nova Fronteira, 1988.

REVISTAREALIDADE. [S. 1.: s. n., 196-].

REVISTAOCRUZEIRO. [S. 1.: s. n., 1928-196-].

REVISTA MANCHETE. Rio de Janeiro: Bloch, n. 848, jan. 1968.

REVISTACLAUDIA. São Paulo: Abril, [19-].

REVISTA VIDAE SAÚDE. [S. 1.: s. n., 1940-196-]. 